\title{
The Effect of Liquidity and Leverage on Profitability in Agricultural Sector Companies
}

\author{
Yusuf Murtadlo Hidayat ${ }^{1, *}$ Budhi Pamungkas Gautama ${ }^{2}$ Cindy Sri Arianti ${ }^{3}$ \\ ${ }^{1}$ Universitas Pendidikan Indonesia \\ ${ }^{2}$ Universitas Pendidikan Indonesia \\ ${ }^{3}$ Universitas Pendidikan Indonesia \\ *Corresponding author.Email: yusuf.murtadlo@upi.edu
}

\begin{abstract}
This study aimed to determine the effect of liquidity and leverage on company profitability. The research method used in this research is a descriptive verificative method. The data used is secondary data, namely the type of data obtained indirectly from the first source (company) in the form of a summary of its performance for six years (2013-2018). The sampling technique used purposive sampling, obtained a sample of 14 companies. The data analysis conducted in this study used panel data regression. After the data was obtained, the classical assumption test was carried out (using the linearity, multicollinearity, heteroscedasticity, and autocorrelation test) with Chow's test and Hausman test. This study indicates that the picture of liquidity is in an unfavorable condition, as well as leverage and profitability are in the unfavorable category, and profitability is not significantly affected by liquidity in a negative direction, while leverage has a significant negative effect on profitability.
\end{abstract}

Keywords: Liquidity, Leverage, Profitability.

\section{INTRODUCTION}

In Indonesia's industry, the capital market has succeeded in attracting many companies to absorb public funds for various purposes. For companies, the capital market can help them get long-term sources of funds and become a means of creating jobs, and because there is no convenant, management can be more accessible in managing company funds. As for investors, because the capital market has various alternative instruments with different risks, investors can freely choose their portfolios according to their risk profile. In Indonesia, the capital market is divided into several institutions. One of the things that many investors are interested in is the Indonesia Stock Exchange.

At the end of 2018, the performance of the stock market in Indonesia scored the worst record in the last three years. This can be seen from the Composite Stock Price Index (IHSG) performance, which experienced minus $-2.54 \%$ from early January to December 2018, even though in 2017 and 2016, IHSG still gave returns of $19.99 \%$ and $15.32 \%$ (Saleh, 2018). The three sectors that had the lowest returns throughout 2018 were agriculture, consumer goods, as well as the property, real estate, and building construction sectors. To provide maximum return for companies and investors, every issuer in these sectors should have good financial performance. According to Munawir (2014), the most widely used parameter to assess a company's performance is to pay attention to its financial ratios. Based on the objective, four financial ratios can be used to assess a company's financial performance, namely profitability, liquidity, solvency (leverage), and activity ratios. When viewed from the track record over the last six years, the Indonesia Stock Exchange sector that has experienced an extreme decline in profits is the agricultural sector. To measure these companies' performance in generating profits, the financial ratio that is often used is the profitability ratio.

Based on researchers' data, the indicator of return on assets in the agricultural sector shows the most extreme decline from year to year, even to the point of showing a negative value. Return on assets in the agricultural sector is in the range of $-0.52-4.57 \%$, with a six-year average of $1.16 \%$. The decline in the average return on assets occurred consecutively from 2014 to 2017, although in 2018 it had experienced a slight increase, the resulting 
value still showed a negative number of $-0.52 \%$. The ideal industry standard for return on assets is 0.3 times or $30 \%$ [1], while as in reference [2] the industry standard for return on assets is 0.0598 times or $5.98 \%$. Referring to the industry standard ratio, the return on assets in the agricultural sector in 2013-2018 was in bad condition because all of them showed a value below $30 \%$ or $5.98 \%$, with fluctuations that tended to decline.

The profitability ratio is influenced by various factors, some of which are liquidity, asset management, and debt management [3]. Based on existing data, researchers saw a phenomenon in two of the three factors above. The two factors are liquidity and leverage. Based on the explanation above, the researcher identified a problem with profitability (measured using return on assets) in agricultural sector companies listed on the IDX in 2013-2018. The factors suspected to be the cause of the problem of profitability in this sector are liquidity (measured using the current ratio) and leverage (measured using the debt to assets ratio). The purpose of this study is to determine an overview of profitability, liquidity, and leverage, to determine the effect of liquidity on profitability, and to determine the effect of leverage on profitability in agricultural companies listed on the Indonesia Stock Exchange (IDX) in 2013-2018.

\section{METHOD}

The method used in this research is descriptive verification with a quantitative approach. The descriptive method is a method that shows how current research is related to the status of a group, object, condition, a system of thought, or a class of events [4]. In comparison, verification research is research to test the truth of the significance between the dependent variable (which is affected) and the independent variable (which affects it) [5]. The variables used in this study are the independent variable and the dependent variable:

\section{a. Independent Variable (X)}

In this study, the independent variables are liquidity and leverage. This variable uses a ratio scale. The independent variable causes the change or the emergence of the dependent variable (Sugiyono, 2017).

\section{b. Dependent Variable (Y)}

In this study, the dependent variable is the level of profitability as Y. This variable uses a ratio scale. The variable whose existence is influenced or becomes the result is the dependent variable. Due to independent variables that affect, the dependent variable can be said to be the variable that is affected [6].

The population in this study were agricultural sector companies listed on the Indonesia Stock Exchange (IDX) in 2013-2018, with a total of 21 companies. In this study, the sampling technique used was purposive sampling.
Based on the predetermined criteria, a sample of 14 companies can be obtained.

The type of data used by researchers in this study is secondary data. Secondary data used in this study are financial reports. The data source is obtained from the Indonesia Stock Exchange with the official website (www.idx.co.id). The data collection technique used in this research is the documentation technique by collecting data in the form of annual reports and financial reports obtained through the Indonesia Stock Exchange's official website (www.idx.co.id). The data analysis used in this study was panel data regression, with a classical assumption test (using linearity, multicollinearity, heteroscedasticity, and autocorrelation tests), Chow's test, and Hausman test.

\section{RESULTS AND DISCUSSION}

As seen in Fig. 1, in 2013 and 2014, the company's average return on assets was $2.439 \%$ and $4.569 \%$, respectively, which means that the company can generate profits using its assets properly and tends to increase. However, in 2015 the agricultural sector experienced a decline in return on assets with an average gain of $1.476 \%$, although this year, the company was still able to utilize assets to generate good profits. Meanwhile, from 2016 to 2018 , the return on assets reached a minus point, which means that most companies in the agricultural sector booked a loss. In 2016 the average return on assets in the sector decreased $107 \%$ from the previous year of $0.108 \%$, then in 2017 , it decreased again by $-694 \%$ with a value of $-0.858 \%$. Unlike the two previous years, in 2018 , the return on assets had increased by $39 \%$, but the value was still minus $-0.522 \%$.

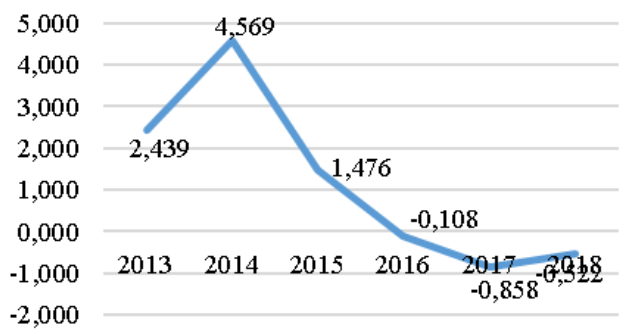

Figure 1. Return on company assets in agriculture sector 2013-2018.

In 2013, as seen in Fig.2 the company's average current ratio was $201.882 \%$, which means the company could meet its short-term liabilities well because the current assets owned were 2.01 times greater than current liabilities. However, in 2014 the company experienced a decrease in liquidity with an average gain of $135.827 \%$, as well as in 2015 , there was a decline with an average gain of $130.747 \%$. These two average gains indicate a decrease in the ability to pay short-term liabilities for two consecutive years. - even though companies in the agricultural sector are still able to pay their short-term 
obligations. One year later, in 2016, companies in the agricultural sector experienced an increase of $153.378 \%$. Companies in the agricultural sector experienced a decrease in the current ratio in a row from 2017 to 2018 , amounting to $148.444 \%$ for 2017 and in 2018 amounting to $142.819 \%$.

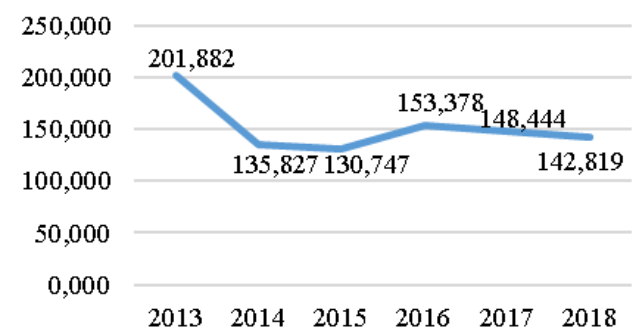

Figure 2. Current ratio of agricultural sector for 20132018

Fig. 3 illustrates the graph of the company's leverage in the agricultural sector as measured by the debt to asset ratio. In 2013, the company's average debt to asset ratio was 0.471 or $47.1 \%$, which means that the average total assets in the agricultural sector in 2013 was $47.1 \%$ financed by debt, and the remaining $52.9 \%$ was financed by own capital. Then in 2014 , the company experienced an increase in debt to asset ratio with an average gain of 0.482 or $48.2 \%$, as well as in 2015 , there was an increase with an average gain of 0.511 or $51.1 \%$, the two average gains show There was an increase in the total number of assets financed by debt, but even though debt increased, the agricultural sector's ability to meet all of its liabilities was still good. In 2016, companies in the agricultural sector experienced a debt to asset ratio decline of $1 \%$ with an average gain of 0.507 or $50.7 \%$. Then, companies in the agricultural sector experienced another increase in debt to asset ratio from 2017 to 2018 , amounting to 0.518 or $51.8 \%$ for 2017 and 2018 by 0.532 or $53.2 \%$.

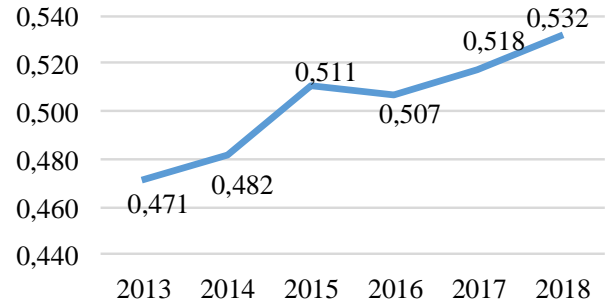

Figure 3. Debt to asset ratio of companies in agriculture sector 2013-2018.

In order to get one of the best models from the threepanel data estimation models, a statistical test is needed with the following steps [7]:

\subsection{Chow-test}

The Chow test results can be explained from the cross-section probability value $\mathrm{F}$ of $0.0002<0.05$ and the cross-section probability of Chi-Square of $0.0000<0.05$.
Thus, H0 is rejected, and the regression model chosen is the Fixed Effect Model.

\subsection{Hausman-test}

The Hausman test results show a Chi-Square probability of $0.0205<0.05$. Thus, H0 is rejected, and a suitable regression model is the Fixed Effect Model.

After selecting the Fixed Effect Model, what is next is done is testing the classical assumptions. In order for the classical assumption test results to obtain an accurate panel regression equation, the panel data regression model must meet the BLUE (Best, Linear, Unbiased, Estimator) criteria which need to be tested statistically as follows:

\subsection{Linearity Test}

Based on the linearity test carried out with the Ramsey-RESET test in Table 4.9, the f-statistical probability is $0.0945>0.05(5 \%)$, so $\mathrm{H} 0$ is rejected. It can be concluded that this regression model can fulfill the linearity assumption, which in turn can affect the dependent variable.

\subsection{Multicollinearity Test}

The multicollinearity test results resulted in the correlation coefficient value of the two independent variables and the dependent variable of -0.579243 below 0.08 , which means that the correlation is low. Thus, this research model does not occur multicollinearity, which ultimately does not affect the dependent variable.

\subsection{Heteroscedasticity Test}

From the output results from White's test, it can be seen that the Prob Obs * R-Squared value is more significant than $\alpha(0.8984>0.05)$. Thus, it can be concluded that the null hypothesis is accepted. There has been a homoscedasticity condition in the regression model, and no heteroscedasticity occurs so that it does not affect the dependent variable.

\subsection{Autocorrelation Test}

The results of autocorrelation testing through the Breusch-Godfrey Serial Correlation LM Test show that the Chi-Square probability value is $0.0140<0.05$. In other words, the F probability value (2.79) of 0.0144 can be called the calculated $F$ probability value. This calculated $\mathrm{F}$ probability value is smaller than the alpha value of 0.05 , which means that $\mathrm{H} 0$ is rejected. So, it can be concluded that this research model occurs autocorrelation, but it does not affect the dependent variable because the data is not time series. 


\subsection{Hypothesis Testing Results}

This test is carried out using the regression significance test and the regression coefficient significance test.

\section{a. Significance Test of Regression ( $F$ statistical test)}

From the results of the $\mathrm{F}$ statistical test using the Fixed Effect model in Table 4.13, it can be seen that the probability value $(\mathrm{F}$-statistic $)=0.000000<0.05$, the null hypothesis is rejected so that the independent variables simultaneously affect the dependent variable.

\section{b. Test of Significance of the Regression Coefficient ( $t$ Statistical Test)}

Based on the results of the regression coefficient significance test (t statistical test) using the Fixed Effect model, the test results can be interpreted as follows:

1) The current ratio shows a probability value of $0.3336>0.05$. Thus, H0 is accepted, which indicates that the current ratio has no significant effect on return on assets in a negative direction.

2) The debt asset ratio shows a probability value of $0.0004<0.05$. Thus, $\mathrm{H} 0$ is rejected, which indicates that the debt asset ratio can significantly affect the return on assets in a negative direction.

\section{CONCLUSION}

The research states that the agricultural sector's level of profitability listed on the Indonesia Stock Exchange in 2013-2018 is in a poor category. This can be seen from the development of the level of profitability in each period, which tends to continue to decline until it is below the industry ideal standard, even showing negative numbers in the last two years. This decline in return on assets indicates that the agricultural sector does not have a good enough ability to generate profits using its assets. The form of assets referred to in this industry is in the form of financial assets and tangible assets such as land, farmers, seeds, and others. In 2013-2018, the agricultural sector had faced various problems such as unstable CPO prices, rampant land fires, reduced human resources in agriculture, the threat of drought and crop failure due to unpredictable weather, and other problems that were mostly related to natural instability, which increases production costs and a decrease in sales, thereby reducing the resulting profit.

The agricultural sector's liquidity level listed on the Indonesia Stock Exchange in 2013-2018 is in an unfavorable category. This can be seen from the development of the liquidity level in each period, which tends to continue to decline. The agricultural sector's current ratio is in the range of $130.75-201.88 \%$, with a six-year average of $152.183 \%$. The decline in the highest level of liquidity was in 2015, then in 2016, it experienced a slight increase but was still below the industry average standard, then again showed a decline until the end of 2018. The decline in sector performance occurred due to deteriorating infrastructure conditions since 2014 due to bad weather. As a result, the production costs of companies in this sector have swelled. This affects increasing the agricultural sector's burden, which results in a decrease in the number of current assets in the company. In these conditions, the company can be said to be still in a healthy financial condition and is able to pay its current obligations, but even so, the current ratio in the agricultural sector continues to decline until the end of 2018. If this decline continues, it is feared that the company will ultimately not be able to pay its obligations.

The level of leverage in the Indonesia Stock Exchange's agricultural sector in 2013-2018 is in a poor category. This can be seen from the development of the level of leverage in each period which tends to continue to rise until it exceeds the industry ideal standard. This indicates that the agricultural sector has experienced a continuous increase in debt since 2013. Although it experienced a decline in 2016, the level of debt to assets ratio returned to high at the end of 2018. Increasing debt in the agricultural sector can increase funding for working capital. However, during the research period, the profit generated did not increase. The increase in profit must be higher than the debt owed to the interest expense that must be paid. Because the use of debt cannot generate high profits, in the end, it results in a decrease in the profits of the agricultural sector because part of the profits is used to pay interest expenses.

The effect of liquidity (current ratio) on profitability (return on assets) in agricultural sector companies listed on the Indonesia Stock Exchange (IDX) in 2013-2018. The results of $t$ statistical testing using the Fixed Effect Model show that this ratio has a probability of 0.3336 more than the significance value of $5 \%$, so $\mathrm{H} 0$ is accepted. So, it can be concluded that the current ratio has no significant effect on profitability in a negative direction, similar with previos research [9].

The effect of leverage (debt to asset ratio) on profitability (return on assets) in agricultural sector companies listed on the Indonesia Stock Exchange (IDX) in 2013-2018. The results of $t$ statistical testing using the Fixed Effect Model show that this ratio has a probability of 0.0004 less than the significance value of $5 \%$, then $\mathrm{H} 0$ is rejected. So, it can be concluded that the debt to asset ratio can have a significant negative effect on profitability. This result is similar to previous research on profitability on return on asset in other sectors [10], [11]. 


\section{REFERENCES}

[1] F. J. Fabozzi and P. P. Peterson, Financial Management and Analysis, 2nd ed. Nashville, TN: John Wiley \& Sons, 2008.

[2] C. Burja, "FACTORS INFLUENCING THE COMPANIES'PROFITABILITY," Annales

Universitatis Apulensis-Series Oeconomica, vol. 13, no. $2,2011$.

[3] D. Tamulevičienè, "Methodology of complex analysis of companies' profitability," J. Entrep.. Sustain. Issu., vol. 4, no. 1, pp. 53-63, 2016.

[4] C. R. Kothari, Research methodology: Methods and techniques. New Age International, 2004.

[5] K. N. Maholtra, Marketing Research: An Applied Orientation Sixth. Pearson Education, 2010.

[6] W. Goddard and S. Melville, Research methodology: An introduction. Juta and Company Ltd, 2004.

[7] S. Chatterjee, B. Price, and A. Hadi, Regression Analysis by Example, 3rd ed. Nashville, TN: John Wiley \& Sons, 2000.
[8] H. Best and C. Wolf, The SAGE handbook of regression analysis and causal inference. London, England: SAGE Publications, 2014.

[9] M. Saragih, Y. Siahaan, R. Purba, and S. Supitriyani, "Pengaruh current ratio terhadap return on asset pada perusahaan sektor aneka industri yang listing di bursa efek Indonesia," Financial: Jurnal Akuntansi, vol. 1, no. 1, pp. 19-24, 2015.

[10] M. Al Nimer, L. Warrad, and R. Al Omari, "The impact of liquidity on Jordanian banks profitability through return on assets," European Journal of Business and Management, vol. 7, no. 7, pp. 229232, 2015.

[11] W. Khidmat and M. Rehman, "Impact of liquidity \& solvency on profitability chemical sector of Pakistan," Economics management innovation, vol. 6, no. 3, pp. 34-67, 2014. W. Khidmat and M. Rehman, "Impact of liquidity \& solvency on profitability chemical sector of Pakistan," Economics management innovation, vol. 6, no. 3, pp. 34-67, 2014. 